\title{
Psychological Analysis of Levels of Communicative Actions Construction
}

\section{Психологічний аналіз рівнів побудови комунікативних дій}

Nataliia Honcharuk

Ph.D. in Psychology, Assistant Professor
Наталія Гончарук

кандидат психологічних наук, доцент

\section{E-mail: goncharuk.nat17@gmail.com orcid.org/0000-0001-9552-0946 \\ Researcher ID: F-8043-2018}

\section{Liana Onufriieva}

Ph.D. in Psychology,

Assistant Professor,

Head of the Department of General and Applied Psychology
Ліана Онуфрісва

кандидат психологічних наук, доцент, завідувач кафедри загальної та практичної психології

E-mail: kpnu_lab_ps@ukr.net orcid.org/0000-0003-2442-4601

Researcher ID: R-5598-2018

Kamianets-Podilskyi National

Ivan Ohiienko University,

Department of General and

Applied Psychology

61, Ohiienka Str., Kamianets-

Podilskyi, Khmelnytskyi region,

Ukraine, 32300
Кам'янець-Подільський національний університет імені Івана Огієнка, кафедра загальної та практичної психології $\square$ вул. Огієнка, 61, Кам'янецьПодільський, Хмельницька обл. Україна, 32300

Original manuscript received March 02, 2018 Revised manuscript accepted September 24, 2018 


\section{ABSTRACT}

On the basis of numeral experimental studies, it is stated that the basic stages of any mental skills formation are physiological and neuropsychological levels. It is proved that physiological support is a complex functional system, which consists in the interaction of individual brain structures and it is an integral system of vital activities of the organism. The neuropsychological level involves the features of the brain organization of the process of communicative interaction. It is shown that the analysis of neuropsychological support of a communicative act enables to realize the essence and mechanisms of communicative processes at the level of brain structures functioning. It is noted that neuropsychological mechanisms, including psychoperceptual, psycholinguistic levels of constructing communicative actions, provide higher levels of the communicative process organization. It is found out that the psychoperceptual level of the communicative actions constructing is the initial stage of communicative interaction, which is represented by social perception as the ability to perceive, understand and shape the impression concerning other people. The theoretical analysis of conceptual approaches to communication research is realized. The direction of communicative actions construction is defined. It is shown that the strategic direction of the communicative functions formation is the need to consider not only the content-based characteristics but also the level ones that determine the sequence and stage-formation of the correction and development work on the formation of communicative skills. On the basis of the research, four basic levels of constructing communicative actions (neuropsychological, psychoperceptual, psycholinguistic and social and psychological) are determined. They allow to prepare psychological work on the development of communicative actions and skills successfully.

The neuropsychological level is established to involve understanding the features of the brain organization of the process of communicative interaction. The psychoperceptual level is represented by the processes of social perception in the system of communicative relationships. The psycholinguistic level is a means of transferring the cognitive and emotional states of the interlocutors through speech. The social and psychological level includes communication as an instrument of socialization. The basic and systemic levels of communicative actions constructing are outlined with the help of the scientific analysis and the strategy on the development of communicative functions is formed on this basis.

Key words: language, speech, communication, cognitive states, communicative functions, communicative actions, neuropsychological, psychoperceptual, psycholinguistic, social and psychological levels of communicative actions. 


\section{Вступ}

Одним із визначальних принципів психологічної роботи 3 розвитку комунікативних функцій $\epsilon$ поетапність іiі побудови, що передбачає формування комунікативних навичок, знання їх змістових характеристик, рівнів функціонування, послідовності становлення.

Змістові характеристики представлено вербальними та невербальними аспектами комунікації, які функціонують у категоріях міжіндивідного індивідно-групового та міжгрупового спілкування. Рівні функціонування означено ступенями організації комунікативних процесів, починаючи 3 нейропсихологічних основ, i завершуючи соціальними аспектами комунікативної взаємодії. Послідовність становлення $є$ методологічним концептом, який виходить із рівневої організації та формується за принципом поступового ускладнення базових комунікативних навичок.

Мета статті полягає у представленні результатів 3'ясування рівнів побудови комунікативних дій та створення на цій основі структурованого підходу до формування комунікативних функцій.

Завдання дослідження:

1. Здійснити теоретичний аналіз напрямів та концепцій дослідження комунікації.

2. Визначити базові та системні рівні побудови комунікативних дій.

3. Розробити стратегії із розвитку комунікативних функцій.

\section{Методи дослідження}

Для реалізації мети нашої статті використано теоретичні методи дослідження, а саме: аналіз психологічної та психолінгвістичної літератури; систематизація; структурування; узагальнення отриманих результатів, методи семіотичного аналізу, згідно яких аналізуються загальні властивості знакових систем у системі комунікації; методи прагматичного аналізу, які спрямовані на дослідження комунікацію у зв'язку із мовними структурами.

\section{Результати та дискусії}

Як свідчать чисельні експериментальні дослідження (Лурия, 2006; Finger, 2001; Lashley, 1929; Hebb, 1949), базовими щаблями формування будь-яких психічних навичок 
є фізіологічний та нейропсихологічний рівні. Фізіологічне забезпечення виступає складною функціональною системою, яка полягає у взаємодії окремих мозкових структур та є цілісною системою життєдіяльності організму. Нейропсихологічний рівень передбачає розуміння особливостей мозкової організації процесу комунікативної взаємодії.

Дослідження, які проводяться у галузі нейропсихології i фізіології, уможливлюють грунтовне вивчення мозкових механізмів функціонування комунікативних дій. Загальновідомими $є$ вчення про мозкову організацію психічних функцій, функціональні блоки мозкової діяльності, явище рефлекторної дуги, першу та другу сигнальну системи, клітинні ансамблі, цитогенетичні поля головного мозку, розвідки яких представлено у працях відомих дослідників (Hebb, 1949; Смирнов, 2004), котрі всебічно розглядають мозкову організацію психічних функцій.

Канадський нейропсихолог Д. Хебб (Hebb, 1949), досліджуючи взаємозв'язок мозкових структур та психічних процесів, доводить, що під час набуття соціального досвіду у процесі навчання різноманітним соціальним та інтелектуальним навичкам у корі головного мозку формуються скоординовані нейронні структури - ансамблі клітин, об'єднані тривкими нейронними зв'язками. Узгоджена робота таких ансамблів формує мережу нейронів, яка активується у необхідний момент. Нейрони проводять електричні або хімічні сигнали між собою та в інші клітини (м'язові, епітеліальні), тим самим зміцнюючи цю систему зв'язків. Чим більше повторень, тим міцнішим виявляється зв'язок. Це $є$ важливим для теорії формування комунікативних навичок - для їх закріплення необхідною є синаптична активація, якість якої залежить від просторово-часових характеристик: чим більше часу використовується для підкріплень і більший обсяг вони займають (безпосередні, асоціативні зв'язки) - тим краще закріплюються навички.

Досліджуючи механізми вищих психічних функцій, О. Лурія (Лурия, 2006), виділив такі три функціональних блоки, необхідних для виконання будь-яких видів діяльності, у тому числі комунікативної: 1) блок активації тонусу; 2) блок отримання та опрацювання інформації; 3) блок програмування та регуляції. Блок активації тонусу, що генерується ретикулярною 
формацією, породжує загальну активність, яка створює підгрунтя для функціонування комунікативних процесів. Блок отримання та опрацювання інформації забезпечує вхідну та репродуктивну частину комунікативного акту - фонематичне сприймання, імпресивне мовлення. Усі ці функції регулюються дією первинних та вторинних ядерних зон кори головного мозку (слухової кори, мовленнєвого та мовленнєво-зорового аналізатора) (Лурия, 2006; Смирнов, 2004). Блок програмування та регуляції формує продуктивну та асоціативно-інтелектуальну складові комунікативного акту. За функціонування цього блоку відповідають третинні зони, надбудовані над усіма відділами мозкової кори. Їх функція - управляти комунікативними процесами, забезпечуючи орієнтувальний, регулюючий та контролюючий компоненти комунікації.

Важливим у плані аналізу процесу комунікації є осмислення вчення про першу та другу сигнальну системи (Павлов, 1951). Перша сигнальна система, яка відповідає за безпосередній вплив сенсорних подразників на аналізаторні системи, у комунікативній взаємодії відображає реальність у формі фонематичних відчуттів та соціальної перцепції. На іï основі функціонує друга сигнальна система система знаків, притаманних лише людині (мовлення як «сигнал сигналів») (Павлов, 1951). Слово виступає соціально спрямованим подразником, яке, формуючи асоціативні зв'язки між учасниками спілкування, забезпечує їхню ефективну взаємодію. Шляхом аналізу значення слів формуються уявлення про комунікативну ситуацію, iï учасників, обставини, умови (Петровский \& Ярошевский, 1990). Аналізуючи цю теорію, дослідник О. Лурія доповнює іiі та вказує на важливу роль акустичного та кінестетичного аналізаторів у забезпеченні комунікативних дій: акустичний відповідає за впізнавання звуків і звукового потоку (гнозис); кінестетичний - за вимову (праксис) (Лурия, 2006).

Розробка теоретичних та практичних аспектів побудови комунікативних дій знаходить своє відображення у положенні про системну мозкову організацію вищих психічних функцій. Різні аналізаторні системи відповідають за формування певних комунікативно-мовленнєвих навичок. Наприклад, акустичний аналізатор, зосереджений у скроневих долях, та кінестетичний, зосереджений у лобних, реалізують перцептивну та мовленнєву 
функції. Процеси слухомовленнєвої та рухової пам'яті, зосереджені в асоціативних зонах, забезпечують здатність зберігати отриману інформацію та використовувати ii під час спілкування. Префронтальні зони лобної долі функціонально регулюють операційні аспекти спілкування - орієнтування у комунікативному завданні, ініціювання комунікації, планування взаємодії. Тім'янопотиличні відділи кори головного мозку дають змогу аналізувати невербальні аспекти спілкування (Лурия, 2006).

Німецький невропатолог К. Бродман йде далі у дослідженнях функціональної організації мозку та розробляє детальну карту цитоархітектонічних зон (Brodmann, 1909). Комунікативну діяльність, за його даними, забезпечують такі поля: 18 - вторинна ядерна зона зорового аналізатора, що відповідає за сприймання писемного мовлення; 37 - акустико-гностичний сенсорний центр, який забезпечує розуміння мовлення; 39, 40 - ангулярна та крайова закрутки зони Верніке, що відповідають за сприймання письмового мовлення та невербальний праксис; 41, 42 - ядерні зони звукового аналізатора, 44 - центр Брока, який контролює звуковимову; 52 ядерна зона слухового аналізатора, яка відповідає за просторове сприймання звуків і мовлення (Finger, 2001).

Натомість, американський психолог та фізіолог К. Лешлі (Lashley, 1929) спростовує позицію тотального локалізаціонізму та своїй роботі «Brain Mechanisms and Intelligence» висуває теорію еквіпотенціальності, в якій вказує на рівноцінне значення різних ділянок мозку для забезпечення психічної діяльності, аргументуючи це тим, що при пошкодженні ділянок кори, відповідальних за певні функції, інші зони беруть на себе їх роль (Lashley, 1929).

Отже, аналіз нейропсихологічного забезпечення комунікативного акту уможливлює усвідомлення сутності та механізмів комунікативних процесів на рівні функціонування загальних мозкових структур. Це дає змогу більш детально проаналізувати інші рівні організації комунікативних дій.

Як свідчать дані психологічних досліджень, одним із них $\epsilon$ nсихоперцептивний рівень, який представлений процесами соціальної перцепції у системі комунікативних взаємин (Bruner, 1983; Kelley, 1973; Кульчицька, 2012; Омельченко, 2008; Поцелуйко, 2015; Худякова, 2003; Маi, 2016). 
У межах комунікативних дій соціальна перцепція виступає як процес сприймання та розуміння інших людей, що відбувається під час комунікативної взаємодії (Bruner, 1983; Treenwald \& Mahrain, 1995; Омельченко, 2008); психологічний чинник сприймання, пізнання, оцінки та прогнозування можливостей соціальних об'єктів (особистостей, груп, суспільства загалом) (Худякова, 2003).

Український соціолог А. Поцелуйко зазначає, що джерелом соціальної перцепції є досвід взаємодії, міжособистісне спілкування та «умоглядні думки різних соціальних авторитетів». Ї̈ продуктами виступають конкретні образи і знакові конструкти, виражені у мовленні та мові (Поцелуйко, 2015). У контексті цієї позиції комунікативні діï $є$ мотивостимулювальну основою соціальної перцепції, та, водночас системною категорією, що включає у себе процес взаємного сприймання як важливу рівневу складову комунікативних інтеракцій.

Для забезпечення цілеспрямованого функціонування комунікативних дій важливим $є$ знання механізмів соціальної перцепції. Міжособистісними i комунікативно спрямованими іiі механізмами визначають розуміння один одного (ідентифікацію, емпатію, атракцію, проекцію); самопізнання (рефлексію); аналіз та прогнозування поведінки партнера по взаємодії (децентрацію, каузальну атрибуцію, стереотипізацію) (Худякова, 2003; Treenwald \& Mahrain, 1995). У системі комунікативних дій ці механізми виступають потужними психодинамічними чинниками комунікації. Вони дають змогу ототожнити i порівняти себе 3 партнерами по спілкуванню, зрозуміти почуття та психічні стани інших осіб, прийняти один одного, узгодити свої дії 3 партнерами по спілкуванню й встановити, на цій основі, позитивні взаємини.

У системі комунікативних дій соціальна перцепція представлена різними компонентами: когнітивним, емоційним, діяльнісним, мотиваційним (Кульчицька, 2012); конативним, когнітивним, виконавчим, диспозиційним (Омельченко, 2008); ціннісно-мотиваційним, гностичним, операційним, особистісним (Худякова, 2003).

Когнітивний компонент відповідає за розуміння інших людей, пізнання їхньої поведінки. Емоційний визначає міру емпатії, співчуття, співпереживання. Діяльнісний зводяться до аналізу та прогнозування процесуальних аспектів комунікативної 
поведінки. Мотиваційний характеризує розуміння тенденцій особистісної спрямованості у спілкуванні (Кульчицька, 2012; Худякова, 2003). Конативний компонент об'єднує уявлення, пов'язані із комунікативною поведінкою індивідів, що регулюється інтеріоризованими нормами та цінностями. Виконавчий розкриває ступінь сформованості вмінь: здатність виділяти експресивні ознаки i позначати емоції словом; диференціювати та узагальнювати експресію; виявляти емоційне ставлення й емпатію. Диспозиційний компонент описує вміння ідентифікувати себе 3 іншими: батьками, однолітками (Омельченко, 2008). Ціннісно-мотиваційний характеризує поєднання мотивів, цінностей, пріоритетів. Гностичний описує знання механізмів соціальної перцепції. Операційний полягає у вмінні володіти уміннями та навичками взаєморозуміння під час комунікативної взаємодії. Особистісний $є$ сукупністю важливих для перебігу соціальної перцепції особистісних якостей учасників комунікативної взаємодії (Худякова, 2003).

Взаємозв'язок соціальної перцепції і комунікативних дій представлений процесами міжособистісного сприймання зовнішніх ознак та внутрішніх властивостей партнерів по спілкуванню, співвіднесенням їх 3 нормами комунікативної поведінки i прогнозуванням, на цій основі, характерного набору комунікативних вчинків. Г. Келлі, котрий вивчав ці процеси, описав зазначені явища терміном «каузальна атрибуція». Він зауважував, що, найчастіше, комунікативні партнери співвідносять причини дій інших людей із власними поведінковими тенденціями. Відтак, причини комунікативної поведінки можуть приписуватись іншим особам (особистісні причини), об'єктам, на які спрямована комунікація (об'єктні причини), зовнішнім обставинам (ситуативні причини). Відповідно, у системі комунікативних дій виділяють особистісну, об'єктну та ситуативну атрибуцію. Така альтернативна комунікативна поведінка $\epsilon$ безпосереднім наслідком соціально спрямованої міжособистісної перцепції (Kelley, 1973).

Сучасні дослідження пов'язують теорію комунікативних дій 3 особистою інформацією про учасників комунікативної взаємодії, інтерпретуючи іiі як контекстуальну та ситуативну, і як таку, що є відкритою для тлумачення (Маi, 2016). Проведені наукові експерименти показали кореляційний взаємозв'язок між такими змінними, як фізична привабливість, емоційність поведінки та 
міжособистісні взаємні ставлення. Так, люди, котрі вважаються привабливими, пов'язані з бажаними особистими атрибутами: вони сприймаються як компетентні, домінуючі, проникливі, дружні, впевнені, популярні (DePaulo, 1992; Dovidio \& Ellyson, 1985; Riggio \& Friedman, 1986). Особи із менш зрілими рисами описуються як покірні, наївні та підпорядковані (Berry, 1991).

Окрім зовнішніх аспектів психологами описано характерні лінгвістичні особливості соціального сприймання. Психологічні експерименти, проведені групою дослідників (Berry, Hiller, Mueller \& Pennebaker, 1997), констатували залежність між типом комунікативних реакцій та соціальною перцепцією. Науковці визначали частоту, з якою використовувались негативні та позитивні висловлювання щодо об'єктів соціального сприймання. Важливими детермінантами перших вражень виявились не лише зовнішні ознаки, а й лінгвістичні особливості самопрезентації, а саме, розмовні стилі та вибір висловлювань у комунікативній взаємодії (запитання або інформування; ініціювання чи реакція). До прикладу, люди, чий мовний стиль був ініціативним, отримали рейтинги вищого рівня, ніж люди з реактивним мовним стилем (Berry, 1997).

Отже, психоперцептивний рівень побудови комунікативних дій $є$ одним із початкових етапів комунікативної взаємодії, який представлено соціальною перцепцією як здатністю сприймати, розуміти та формувати враження про інших людей.

Поряд із соціальною перцепцією комунікативна взаємодія передбачає активне спілкування учасників комунікативного процесу, яке уможливлюється засобами мовлення. Виокремлення основних понять мовленнєвої взаємодії описується психолінгвістичним рівнем побудови комунікативних дій. Психолінгвістичний рівень побудови комунікативних дій є середовищем поширення лінгвістичної інформації у комунікативному просторі, засобом передачі емоційних станів співрозмовників. Його вивчають психологи та мовознавці (Бацевич, 2009; Выготский, 1996; Горох \& Карпалюк, 2009; Куранова, 2013; Леонтьев, 2005; Osgood \& Sebeok, 1965). Психолінгвістичні дослідження представлені вченнями про взаємозв'язок мовлення та мислення (гіпотеза Сепіра-Уорфа), теорією мовленнєвого пристосування до середовища (Osgood \& Sebeok, 1965) теорією мовленнєвої діяльності (Леонтьев, 2005), положеннями про роль у комунікативній взаємодії ефективної 
побудови висловлювань (Chomsky, 1965), концепцією соціальної організації мови та мовлення (Выготский, 1996), доктриною про вербальну комунікативну поведінку (Skinner, 1957).

У спілкуванні мовлення i мова, які функціонують для передачі інформації, думок, почуттів, уможливлюють використання вербальних та невербальних сигналів для встановлення комунікативної взаємодії між людьми. Мовлення служить потужним поштовхом суспільного розвитку, оскільки забезпечує не лише безпосередню взаємодію, а також дає змогу передавати інформацію на відстані, формує інтелектуальний та практичний комунікативний досвід в історичному плані. Дослідник Б. Скіннер окреслював мовлення як форму вербальної комунікативної поведінки, обумовлену комунікативною ситуацією (Skinner, 1957), О. Леонтьєв (Леонтьев, 2005) описував його як засіб комунікації, а дослідниця С. Куранова (2013) розглядає як динамічне утворення, яке проходить становлення в онтогенетичному плані та розвивається у процесі соціально-психологічного навчання.

У межах психолінгвістичної теорії комунікації дослідниками (Osgood \& Sebeok, 1965) розвивається теорія мовленнєвого пристосування до середовища та описуються три його рівні: репрезентації; інтеграції та самостимуляції; рецепції і моторної кодифікації. Рівень рецепції і моторної кодифікації є базовим та від нього залежить сприймання мовлення. Автори наводять приклад, якщо слухач не бачить артикуляцію мовця, то рівень розуміння ним зверненого мовлення знижується на 20\%. Наступними є рівні інтеграції, самостимуляції та репрезентації. На основі аналізу цих рівнів авторами доводиться, що мовленнєва діяльність розвивається лише в умовах комунікативної взаємодії (Osgood \& Sebeok, 1965).

Згідно концепції соціальної організації мови та мовлення, представленої Л. Виготським (1996), мовлення людини є явищем соціальним i опосередковується системою суспільних взаємин. Послідовником Л. Виготського $є$ О. Леонтьєв, який займався дослідженням мовлення у контексті людської діяльності (Леонтьев, 2005). Теорія мовленнєвої діяльності, яку розвивав О. Леонтьєв, опосередковує мовлення з різними видами діяльності, оскільки, подібно до них, складається 3 послідовних етапів, представлених мотивом, орієнтуванням, плануванням, реалізацією, контролем та оцінкою (Леонтьев, 2005). Водночас, автором зазначено, що 
мовлення може виступати також допоміжним засобом діяльності і виступати як лінгвістичний феномен у комунікативному контексті (Леонтьев, 2005). Американський психолінгвіст, виходець із України, Н. Хомський (Chomsky, 1965) є автором теорії генеративної граматики, у якій представлено положення про роль ефективного структурування висловлювань у комунікативній взаємодії. Дослідник стверджує, що мовлення є асемантичним і значення не відіграє важливої ролі, натомість найбільш актуальним $є$ форма подачі матеріалу.

Деякі сучасні зарубіжні дослідники надають особливого значення стимулам та мовленнєвим інтенціям, виходячи 3 яких класифікують комунікативні дії (Manera, von der Lühe \& Schilbach, 2016).

Серед українських учених, котрі вивчають лінгвістичні основи комунікації, слід відзначити Ф. Бацевича, Г. Горох, В. Карпалюк авторів дослідження мовного коду у процесах спілкування, механізмів формування мовлення у різних комунікативних умовах. Так, Ф. Бацевич (2009) аналізує загальні закони спілкування людей за допомогою мови, організацію семіотичних систем у процесах комунікативної взаємодії особистості, вплив на засоби мови психічних чинників. Сучасні лінгвісти Г. Горох та В. Карпалюк (Горох \& Карпалюк, 2009) досліджують процесуально-логічні аспекти мовлення та їх місце у структурі комунікативного акту.

Важливим у плані реалізації методологічних питань із розвитку мовлення та комунікації є соціально-психологічне навчання психолінгвістичним навикам. У цьому контексті дослідник J. Alien (1986), аналізуючи комунікативні практики, описує трифокальну модель лінгвістико-психологічного навчання, у якій виділяє три підходи до формування комунікативних навичок: структурноаналітичний (тип A), функціонально-аналітичний (тип В), неаналітичний (тип C) (Alien, 1986).

Структурно-аналітичний підхід передбачає необхідність фокусування уваги на граматичних та формальних особливостях мови. 3 цією метою застосовуються контрольовані граматичні методи навчання, середньо-орієнтована практика. Функціональноаналітичний дає змогу зосередитись на дискурсивних особливостях мови i передбачає використання контрольованих комунікативних методів навчання, середовищну та інформаційно-орієнтовану 
практику. Неаналітичний передбачає вільне, необмежене використання мови як інструменту спілкування. В учасників комунікативного процесу діяльність включає багато практики на основі особистісного досвіду та інтересів. У ході використання цього підходу функціонують повністю комунікативні методи навчання, орієнтовані на повідомлення та комунікативні висловлювання (Alien, 1986). Використання цих методів уможливлює інтегровано підійти до проблеми формування навичок комунікації з точки зору лінгвістичного підходу.

Невід'ємною психологічною характеристикою комунікативних дій є позитивна спрямованість комунікації. Дослідниця Т. Космеда, котра досліджує цю проблему, акцентує увагу на ролі дискурсивних висловлювань із позитивним денотативно-сигніфікативним значенням (до прикладу: добре, гаразд, чудово, прекрасно) у формуванні міжособистісної комунікації (Космеда, 2011). На іiі думку, такі дискурсивні вирази забезпечують виконання низки функцій у повсякденній комунікації: забезпечують позитивну атмосферу; формують почуття довіри до співрозмовника; знижують тривогу i негативні емоції (там само, 2011). Характер комунікації багато в чому залежить від ментальних якостей особистості, культури соціуму, в якому зростала особистість, та особистих цінностей, які знову ж таки беруть витоки 3 ментальності соціуму (Kim, Joshanloo \& Foldesi, 2018). Отже, аналіз психолінгвістичного рівня побудови комунікативних дій уможливлює дослідження загальних законів спілкування людей за допомогою мови, організацію мовного знакового коду у процесах комунікативної взаємодії, що вказує на тісний взаємозв'язок процесів мовлення та комунікації.

Наступним у формуванні взаємодії є соціально-психологічний рівень побудови комунікативних дій, у межах якого вони розглядаються як інструмент соціалізації. Їх роль у соціальному розвитку розкривають дослідники Treenwald та Mahrain (1995), описуючи іï як комунікативний обмін груповими цінностями, думками, поглядами, інформацією; належність до спільноти; засвоєння загальних норм колективної поведінки; координування взаємин (Treenwald \& Mahrain, 1995).

Як відомо, комунікація здійснюється в умовах соціальної групи. Згідно поглядів дослідників А. Петровського i В. Шпалінського, групою є певна кількість людей, об'єднана за 
ознакою спільної діяльності (Петровский \& Шпалинский, 1978); соціальна організація, в якій забезпечується з'єднання окремих сил в об'єднану суспільну силу, що забезпечує досягнення єдиної мети (Homans, 1958).

Спільна діяльність є важливим фактором функціонування соціальної спільноти. Вона опосередковує комунікативні стосунки, які формуються у межах соціальної взаємодії (Андреева \& Донцова, 1981). Групові та соціальні процеси залежать від індивідуальних особливостей комунікативної поведінки ії членів. Висока активність спонукає творчо, ініціативно підходити до вирішення колективних справ, знаходити оригінальні напрями колективних рішень. Низька активність гальмує груповий розвиток. Важливим показником групової комунікативної активності $€$ надситуативність, яка передбачає вихід за межі ситуації. У згуртованому колективі його члени виявляють товариську солідарність, їх вчинки характеризує потреба діяти спільно, що $є$ ознакою ціннісно-орієнтаційної спрямованості комунікації.

Український дослідник О. Холод розглядає комунікативні дії у межах аналізу соціальних комунікацій та акцентує увагу на проблемах соціально-комунікаційного інжинірингу, який зводить до процесу формування й реалізації комунікативних технологій. Зазначені технології включають спрямовані стратегії, тактичні прийоми та моделі комунікативних дій, за допомогою яких формується маніпулятивна поведінка 3 позитивно- чи негативно спрямованими наслідками (Холод, 2013).

Проблеми соціальної комунікації як системного утворення, основою якого $є$ низка комунікативних дій, детально аналізує О. Соколов (Соколов, 2002) такі комунікативні дії як спілкування, соціальне запам'ятовування, функціонування інформаційних структур, передача соціальної інформації за допомогою комунікативних каналів, інформаційна технологізація суспільства, комунікаційні відносини й інформаційна культура. Bci ці комунікативні дії уможливлюють розвиток соціально-комунікаційної культури суспільства, що підіймає їх на найбільш високий щабель комунікативного розвитку.

\section{Висновки}

Узагальнюючи результати психологічного аналізу рівнів побудови комунікативних дій, можна зробити наступні узагальнення. 
Комунікативні дії досліджуються на таких основних рівнях: a) нейропсихологічному, що передбачає усвідомлення мозкової організації процесу комунікативної взаємодії; психоперцептивному представленому процесами соціальної перцепції у системі комунікативних взаємин; психолінгвістичному - як рівню, на якому відбувається передача інформації та почуттів засобами мовлення; соціально-психологічному - рівню, на якому комунікація розглядається як інструмент соціалізації. Знання цих рівнів дає змогу сформувати методологічну стратегію $i$ тактику побудови комунікативних дій за принципом поступового ускладнення базових функцій.

1. У межах нейропсихологічного блоку враховуються такі аспекти побудови комунікативних дій:

- залежність синаптичної активації від просторово-часових характеристик (використання асоціативних зв'язків; часових обмежень у комунікації);

- послідовність опрацювання комунікативної інформації: урахування блоків активації; опрацювання; програмування та регуляції інформації;

- роль акустичного та кінестетичного аналізаторів у забезпеченні комунікативних дій.

2. У межах психоперцептивного блоку формуються:

- вміння пізнавати, оцінювати та прогнозувати можливості соціальних об’єктів 3 урахуванням когнітивного, емоційного, мотиваційного, операційного, особистісного та ін. компонентів;

- навички розуміння один одного шляхом активації процесів ідентифікації, емпатії, атракції, проекції;

- здатність до самопізнання та рефлексії;

- вміння аналізувати та прогнозувати поведінку партнера на основі децентрації, каузальної атрибуції, стереотипізації;

- оцінку зовнішніх та внутрішніх (лінгвістичних, інтелектуальних) диспозицій партнера.

3. У межах психолінгвістичного блоку забезпечуються:

- урахування рівнів (репрезентації, інтеграції, моторної кодифікації) під час побудови мовленнєвої комунікації;

- опосередкування процесуально-логічних аспектів функціонування комунікативних дій: орієнтування, планування, реалізації, контролю та оцінки; 
- структурування висловлювань у комунікативній взаємодії;

- зосередження на дискурсивних особливостях мови;

- формування позитивної спрямованості комунікації.

4. У межах соціально-психологічного блоку акцентується увага на:

- спільній діяльності як факторові опосередкування комунікативних стосунків;

- індивідуальних особливостях комунікативної поведінки членів соціальної спільноти;

- формуванні навичок соціально-комунікаційного інжинірингу, який полягає у цільовому використанні комунікативних технологій.

Здійснення дослідження не вичерпує всіх аспектів означеної проблеми. Перспектива подальших розвідок полягає в експериментальному вивченні чинників та психологічних особливостей комунікації відповідно до рівня організації комунікативних дій.

\section{Література}

Бацевич, Ф. Основи комунікативної лінгвістики. Київ : Академія, 2009. 376 с.

Выготский, Л.С. Мышление и речь. Психологические исследования. Москва : Лабиринт, 1996. 416 с.

Горох, Г.В., Карпалюк, В.С. Комунікативна лінгвістика. Кам'янецьПодільський : Зволейко, 2009. 283 с.

Космеда, Т.А. Позитивна тональність комунікації як чинник взаєморозуміння. Лінгвістичні дослідження. 2011. Вип. 32. С. 216-221.

Кульчицька, А.В. Структурно-функціональний підхід до соціальної перцепції в системі підготовки фахівців. Режим доступу: http://www.nbuv.gov.ua/ejournals/Vnadps/2012_1/12kavspf.pdf.

Куранова, С.I. Основи психолінгвістики. Київ : Академія, 2013. 208 с.

Леонтьев, А.А. Основы психолингвистики. Москва : Смысл, 2005. 288 с.

Лурия, А.Р. Основы нейропсихологии. Москва : Академия, 2006. 384 с.

Межличностное восприятие в группе / [под ред. Г.М. Андреевой, А.И. Донцова]. Москва : Изд-во МГУ, 1981. 295 с.

Омельченко, І.М. Змістова модель компонентів дослідження соціальної перцепції у дітей дошкільного віку 3 дитячим церебральним паралічем. Вісник Луганського національного університету імені Тараса Шевченка. Педагогічні науки. 2008. № 12 (151). С. 201-206.

Петровский, А.В., Шпалинский, В.В. Социальная психология коллектива. Москва : Просвещение, 1978. 176 с.

Поцелуйко, А.О. Соціальна перцепція: історико-філософські та загальнопсихологічні передумови дослідження. Соціологія. Социология. Sociology. 2015. № 4. C. 54-61. 
Сигнальные системы. Психология / [под общ. ред. А.В. Петровского, М.Г. Ярошевского]. Москва : Политиздат, 1990. 494 с.

Смирнов, В.М. Нейрофизиология и высшая нервная деятельность детей и подростков. Москва : Академия, 2004. 400 с.

Соколов, А.В. Общая теория социальной коммуникации. Санкт-Петербург : Изд-во Михайлова В.А., 2002. 461 с.

Холод, О. Соціальні комунікації як поняття в науковій галузі «Соціальні комунікації». Psycholinguistics. Психолінгвістика. Психолингвистика. 2013. Вип. 12. С. 286-293.

Худякова, B.I. Соціальна перцепція як чинник оптимізації управлінської діяльності керівника середньої загальноосвітньої школи : автореф. дис. ... канд. психол. наук : 19.00.05. Київ. 2003. 20 с.

Alien, J.P.B. (1986). Functional-Analytic Course Design and the Variable Focus Curriculum1. In C.J. Brumfit (Ed.), The Practice of Communicative Teaching (pp. 3-25). Oxford-New York-Beijing-Frankfurt-Sao Paulo-Sydney-TokyoToronto Pergamon Press.

Bach, K., \& Harnish, R.M. (1979). Linguistic Communication and Speech Acts. Cambridge, MA : MIT Press.

Diane S. Berry, James W. Pennebaker, Jennifer S. Mueller, \& Wendy S. Hiller (1997). Linguistic bases of social perception. Personality \& Social Psychology Bulletin, 23(5), 526-537. https://doi.org/10.1177/0146167297235008

Brodmann Korbinian (1909). Vergleichende Lokalisationslehre der Grosshirnrinde : in ihren Principien dargestellt auf Grund des Zellenbaues. Leipzig : Johann Ambrosius Barth Verlag.

Bruner, J. (1983). Child's talk: Learning to use language. New York, London : W.W. Norton \& Co.

Finger, S. (2001). Origins of Neuroscience: A History of Explorations Into Brain Function. Oxford : Oxford University Press.

Garnham, A. (1985). Psycholinguistics: Central Topics. London and New York : Methuen.

Lashley, K.S. (1929). Brain mechanisms and intelligence: A quantitative study of injuries to the brain. Chicago : University of Chicago Press.

Kelley, H.H. (1973). The Processes of Causal Attribution1. American Psychologist, 28 (2), 107-128. http://dx.doi.org/10.1037/h0034225

Kim, M.Y., Joshanloo, M., \& Foldesi, E. (2018). Relationship Between Emotional Expression Discrepancy and Life Satisfaction Across Culture and Personal Values. Current Psychology. https://doi.org/10.1007/s12144-018-9826-6

Mai, J.E. (2016). Personal Information as Communicative Acts. Ethics and Information Technology, 18(1), 51-57. https://doi.org/10.1007/s10676-016-9390-4

Manera, V., von der Lühe, T., Schilbach, L., \& et al. (2016). Communicative interactions in point-light displays: Choosing among multiple response alternatives. Behavior Research Methods, 48(4), 1580-1590. https://doi. org/10.3758/s13428-015-0669-x

Osgood, Ch.E., \& Sebeok, Th.A (Eds.). (1965). Psycholinguistics: a survey of theory and research problems. Bloomington, Indiana : Indiana University Press.

Treenwald, A.T., \& Mahrain, R.B. (1995). Implicit Social Cognition: attitudes, selfesteem and stereotypes. Psychological Review, 102(1), 4-27.

Hebb, D.O. (1949). The Organization of Behavior: a Neuropsychological Theory. New York : Wiley. 
Homans, G.C. (1958). The Human group. Social behavior as exchange. Social Behavior as Exchange, 63(6), 597-606, Emile Durkheim-Georg Simmel, New York : Harcourt Brace Jovanovich.

Chomsky, N. (1965). Aspects of the Theory of Syntax. Cambridge : Massachusetts : MIT Press.

Skinner, B.F. (1957). Verbal behavior. New York : Appleton-Century-Crofts.

\section{References}

Bacevych, F. (2009). Osnovy komunikatyvnoi lingvistyky [The fundamentals of communicative linguistics]. Kyiv : Akademija [in Ukrainian].

Vygotskij, L.S. (1996). Myshlenie i rech. Psihologicheskie issledovanija [Thought and speech. Psychological research]. Moscow : Labirint [in Russian].

Goroh, G.V., \& Karpaljuk, V.S. (2009). Komunikatyvna lingvistyka [Communicative linguistics]. Kamjanec-Podilskyj : Zvolejko [in Ukrainian].

Kosmeda, T.A. (2011). Pozytyvna tonalnist komunikacii jak chynnyk vzajemorozuminnja [Positive tone of communication as a factor of mutual understanding]. Lingvistychni doslidzhennja - Linguistic research, 32, 216-221 [in Ukrainian].

Kulchycka, A.V. (2012). Strukturno-funkcionalnyj pidhid do socialnoi percepcii $\mathrm{V}$ systemi pidgotovky fahivciv [Structural and functional approach to social perception in the system of specialists' training]. Psyhologichni nauky - Psychological sciences, 1, URL: http://www.nbuv.gov.ua/e-journals/ Vnadps/2012_1/12kavspf.pdf. [in Ukrainian].

Kuranova, S.I. (2013). Osnovy psyholingvistyky [The fundamentals of psycholinguistics]. Kyiv : Akademija [in Ukrainian].

Leontev, A.A. (2005). Osnovy psiholingvistiki [The fundamentals of psycholinguistics]. Moscow : Smysl [in Russian].

Lurija, A.R. (2006). Osnovy nejropsihologii [The fundamentals of neuropsychology.]. Moscow : Akademija [in Russian].

Andreeva, G.M., \& Doncova, A.I. (1981). Mezhlichnostnoe vosprijatie v gruppe [Interpersonal perception in the group]. Moscow : Izd-vo MGU [in Russian].

Omelchenko, I.M. (2008). Zmistova model komponentiv doslidzhennja socialnoi percepcii $\mathrm{u}$ ditej doshkilnogo viku $\mathrm{z}$ dytjachym cerebralnym paralichem [The content model of the components of the research on social perception in preschool children with cerebral palsy]. Visnik Luganskogo natsionalnogo universitetu imeni Tarasa SHevchenka. Pedagogichni nauki. - Bulletin of Luhansk Taras Shevchenko National University. Pedagogical Sciences, 12, 201-206 [in Ukrainian].

Petrovskij, A.V., \& Shpalinskij, V.V. (1978). Socialnaja psihologija kollektiva [Social psychology of the collective]. Moscow : Prosveshhenie [in Russian].

Petrovskij, A.V., \& Jaroshevskij, M.G. (1990). Signalnye sistemy. Psihologija [Signal systems. Psychology]. Moscow : Politizdat [in Russian].

Pocelujko, A.O. (2015). Socialna percepcija: istoryko-filosofski ta zagalnopsyhologichni peredumovy doslidzhennja [Social perception: historical and philosophical and general psychological preconditions of the research]. Sociologija - Sociology, 4, 54-61 [in Ukrainian].

Smirnov, V.M. (2004). Nejrofiziologija $i$ vysshaja nervnaja dejatelnost detej $i$ podrostkov [Neurophysiology and higher nervous activities of children and teenagers]. Moscow : Akademija [in Russian]. 
Sokolov, A.V. (2002). Obshhaja teorija socialnoj kommunikacii [General Theory of Social Communication]. St. Petersburg : Izd-vo Mihajlova V.A. [in Russian].

Holod, O. (2013). Socialni komunikacii jak ponjattja v naukovij galuzi «Socialni komunikacii» [Social communications as a concept in the scientific field «Social Communications»]. Psyholingvistyka - Psycholinguistics, 12, 286-293.

Hudjakova, V.I. (2003). Socialna percepcija jak chynnyk optymizacii upravlinskoi dijalnosti kerivnyka serednoi zagalnoosvitnoi shkoly [Social perception as a factor in the optimization of managerial activities of the head of a secondary school]. Candidate's thesis. Kyiv [in Ukrainian].

Alien, J.P.B. (1986). Functional-Analytic Course Design and the Variable Focus Curriculum1. In C.J. Brumfit (Ed.), The Practice of Communicative Teaching (pp. 3-25). Oxford-New York-Beijing-Frankfurt-Sao Paulo-Sydney-TokyoToronto Pergamon Press.

Bach, K., \& Harnish, R.M. (1979). Linguistic Communication and Speech Acts. Cambridge, MA : MIT Press.

Diane S. Berry, James W. Pennebaker, Jennifer S. Mueller, \& Wendy S. Hiller (1997). Linguistic bases of social perception. Personality \& Social Psychology Bulletin, 23(5), 526-537. https://doi.org/10.1177/0146167297235008

Brodmann Korbinian (1909). Vergleichende Lokalisationslehre der Grosshirnrinde : in ihren Principien dargestellt auf Grund des Zellenbaues. Leipzig : Johann Ambrosius Barth Verlag.

Bruner, J. (1983). Child's talk: Learning to use language. New York, London : W.W. Norton \& Co.

Finger, S. (2001). Origins of Neuroscience: A History of Explorations Into Brain Function. Oxford : Oxford University Press.

Garnham, A. (1985). Psycholinguistics: Central Topics. London and New York : Methuen.

Lashley, K.S. (1929). Brain mechanisms and intelligence: A quantitative study of injuries to the brain. Chicago : University of Chicago Press.

Kelley, H.H. (1973). The Processes of Causal Attribution1. American Psychologist, 28 (2), 107-128. http://dx.doi.org/10.1037/h0034225

Kim, M.Y., Joshanloo, M., \& Foldesi, E. (2018). Relationship Between Emotional Expression Discrepancy and Life Satisfaction Across Culture and Personal Values. Current Psychology. https://doi.org/10.1007/s12144-018-9826-6

Mai, J.E. (2016). Personal Information as Communicative Acts. Ethics and Information Technology, 18(1), 51-57. https://doi.org/10.1007/s10676-016-9390-4

Manera, V., von der Lühe, T., Schilbach, L., \& et al. (2016). Communicative interactions in point-light displays: Choosing among multiple response alternatives. Behavior Research Methods, 48(4), 1580-1590. https://doi. org/10.3758/s13428-015-0669-x

Osgood, Ch.E., \& Sebeok, Th.A (Eds.). (1965). Psycholinguistics: a survey of theory and research problems. Bloomington, Indiana : Indiana University Press.

Treenwald, A.T., \& Mahrain, R.B. (1995). Implicit Social Cognition: attitudes, selfesteem and stereotypes. Psychological Review, 102(1), 4-27.

Hebb, D.O. (1949). The Organization of Behavior: a Neuropsychological Theory. New York : Wiley.

Homans, G.C. (1958). The Human group. Social behavior as exchange. Social Behavior as Exchange, 63(6), 597-606, Emile Durkheim-Georg Simmel, New York : Harcourt Brace Jovanovich. 
Chomsky, N. (1965). Aspects of the Theory of Syntax. Cambridge : Massachusetts : MIT Press.

Skinner, B.F. (1957). Verbal behavior. New York : Appleton-Century-Crofts.

\section{АНОТАЦІЯ}

На основі чисельних експериментальних досліджень констатовано, що базовими щаблями формування будь-яких психічних навичок $\epsilon$ фрізіологічний та нейропсихологічний рівні. Підтверджено, що фізіологічне забезпечення виступає складною функціональною системою, яка полягає у взаємодії окремих мозкових структур $i \epsilon$ цілісною системою життєдіяльності організму, а нейропсихологічний рівень передбачає розуміння особливостей мозкової організації процесу комунікативної взаємодії. Показано, що аналіз нейропсихологічного забезпечення комунікативного акту дає змогу усвідомити сутність та механізми комунікативних процесів на рівні функціонування мозкових структур. Зазначено, що нейропсихологічні механізми, до них відносяться психоперцептивний, психолінгвістичний рівні побудови комунікативних дій, забезпечують вищі рівні організаціі комунікативного процесу. З'ясовано, що психоперцептивний рівень побудови комунікативних дій $\epsilon$ початковим етапом комунікативної взаємодії, який представлено соціальною перцепцією як здатністю сприймати, розуміти та формувати враження про інших людей. Здійснено теоретичний аналіз концептуальних підходів до дослідження комунікації. Визначено змістове спрямування побудови комунікативних дій. Показано, що стратегічним напрямом формування комунікативних функцій є необхідність ураховувати не лише змістові, а й рівневі характеристики, які визначають послідовність та етапність корекційно-розвивальної роботи зі становлення комунікативних навичок. На основі дослідження визначено чотири основних рівні побудови комунікативних дій (нейропсихологічний, психоперцептивний, психолінгвістичний та соціально-психологічний), які дають змогу успішно налагоджувати психологічну роботу з розвитку комунікативних дій та навичок. Встановлено, що нейропсихологічний передбачає розуміння особливостей мозкової організації процесу комунікативної взаємодії; психоперцептивний представлено процесами соціальної перцепції у системі комунікативних взаємин; психолінгвістичний є засобом передачі когнітивних та емоційних станів співрозмовників за допомогою мовлення; соціально-психологічний розглядає комунікацію як інструмент соціалізації. Шляхом наукового аналізу окреслено базові і системні рівні побудови комунікативних дій та на цій основі сформовано стратегію $з$ розвитку комунікативних функцій. 
Ключові слова: мова, мовлення, комунікація, когнітивні стани, комунікативні функції, комунікативні дії, нейропсихологічний, психоперцепивний, психолінгвістичний, соціально-психологічний рівні комунікативних дій.

\section{Гончарук Наталья, Онуфриева Лиана. Психологический анализ уровней построения коммуникативных действий}

\section{АННОТАЦИЯ}

На основе многочисленных экспериментальных исследований констатировано, что базовыми ступенями формирования любых психических навыков является физиологический и нейропсихологический уровни. Подтверждено, что физиологическое обеспечение выступает сложной функциональной системой, которая заключается во взаимодействии отдельных мозговых структур и является целостной системой жизнедеятельности организма, а нейропсихологический уровень предполагает понимание особенностей мозговой организации процесса коммуникативного взаимодействия. Показано, что анализ нейропсихологчческого обеспечения коммуникативного акта позволяет осознать сущность и механизмы коммуникативных процессов на уровне функционирования мозговых структур. Отмечено, что нейропсихологические механизмы, $k$ которым относятся психоперцептивный, психолингвистический уровни построения коммуникативных действий, обеспечивают высокие уровни организации коммуникативного процесса. Выяснено, что психоперцептивный уровень построения коммуникативных действий является начальным этапом коммуникативного взаимодействия, который представлен социальной перцепцией как способность воспринимать, понимать и формировать впечатление о других людях. Осуществлён теоретический анализ концептувальних подходов к исследованию коммуникации. Определены содержательное направление построения коммуникативных действий. Показано, что стратегчческим направлением формирования коммуникативных функций является необходимость учитывать не только содержание, но и уровни характеристики, определяющие последовательность и этапность коррекционно-развивающей работы по становлению коммуникативных навыков. На основе исследования определены четыре основных уровня построения коммуникативных действий (нейропсихологический, психоперцептивный, психолингвистический и социально-психологический), которые позволяют успешно налаживать психологическую работу по развитию коммуникативных действий и навыков. Установлено, что нейропсихологический предполагает понимание особенностей 
мозговой организации процесса коммуникативного взаимодействия; психоперцептивный представлен процессами социальной перцепции в системе коммуникативных отношений; психолингвистический является средством передачи когнитивных и эмоциональных состояний собеседников с помощью речи; социально-психологический рассматривает коммуникацию как инструмент социализации. Путём научного анализа обозначены базовые и системные уровне построения коммуникативных действий и на этой основе сформирована стратегия по развитию коммуникативных функций.

Ключевые слова: язык, речь, коммуникация, когнитивные состояния, коммуникативные функции, коммуникативные действия, нейропсихологический, психоперцепивный, психолингвистический, социально-психологчческий уровни коммуникативных действий. 